\title{
Comparison of bone morphogenetic protein and autologous grafting in the treatment of limb long bone nonunion: a systematic review and meta-analysis
}

\author{
Yong-Qiang Zhou ${ }^{1,2}$, Hong-Liang Tu ${ }^{1,2}$, Yan-Ji Duan ${ }^{1,2}$ and Xiao Chen ${ }^{1,2^{*}}$ (D)
}

\section{Abstract}

Background: Bone morphogenetic proteins (BMPs) have strong bone induction propertiles and can promote healing of fractures and other defects. However, BMP treatment efficacy for no nonunion remains controversial. The aim of this meta-analysis was to synthetically evaluate the a plus bone grafting (observation group) versus autologous bone graft contro/group) for limb long bone nonunion.

Methods: PubMed, Embase, Web of Science, Cochrane Library OVID, CIMK, Weipu Journal, Chinese Biomedical Literature, and WanFang were searched for randomized a id no andomized controlled trials published before November 2019. A meta-analysis of outcome indicators w perfo med using RevMan 5.3 and Stata 12.0.

Results: Five randomized and four non-randomize controlle als involving 30-124 cases were included, with a total of 655 nonunion cases. There were no signith yrou differences in postoperative healing rate, infection, and secondary operation rates $(P>0.05)$, but the stuo, ro oup demonstrated significantly shorter mean healing time (WMD $=-1.27,95 \% \mathrm{Cl}-1.67$ to $-0.8, \quad 0.00001)$, a greater frequency of excellent/good post-treatment limb function ( $R R=1.18,95 \% \mathrm{Cl} 1.01-12 \mathrm{~h} P=0$. and lower intraoperative blood loss $(P<0.05)$. Alternatively, the hospitalization cost was significantly higher in the study group $(P<0.01)$.

Conclusions: Bone morphogenetic ttein id a viable alternative to autologous bone grafting, with potential advantages of accelerated frarture heam $y$ and improved postoperative function.

Keywords: Bone morphogenelic jury cin, Autologous bone graft, Nonunion, Long bone, Meta-analysis

\section{Introduction}

Nonunion of lo o bone ctures is observed in 2.5 to $46 \%$ of cases dep ding on the location and severity of damage to the bont, oft tissue, and vascular structures [1]. Tre me nt of nonunion involves mechanical fixation

\section{vrres andence: 342918992@qq.com}

th eparment of Orthopedic Surgery, The First People's Hospital of Neijlà Neijiang 641000, Sichuan, China

${ }^{2}$ The Department of Neonatology, The First People's Hospital of Neijiang, Neijiang 641000, Sichuan, China and biological repair, often requiring autologous bone grafting to assist in bone healing. At present, autologous bone is the only graft with the capacities for osteogenesis, bone induction, and bone conductivity, and as such is still the "gold standard" for bone graft material $[1,2]$. The main source for autologous bone for grafting is the iliac crest due to its accessibility and the abundance of progenitor cells and growth factors [1, 2]. However, obtaining autologous bone frequently results in minor complications (9-39\%) and occasionally severe

(c) The Author(s). 2020 Open Access This article is licensed under a Creative Commons Attribution 4.0 International License, which permits use, sharing, adaptation, distribution and reproduction in any medium or format, as long as you give appropriate credit to the original author(s) and the source, provide a link to the Creative Commons licence, and indicate if changes were made. The images or other third party material in this article are included in the article's Creative Commons. licence, unless indicated otherwise in a credit line to the material. If material is not included in the article's Creative Commons licence and your intended use is not permitted by statutory regulation or exceeds the permitted use, you will need to obtain permission directly from the copyright holder. To view a copy of this licence, visit http://creativecommons.org/licenses/by/4.0/ The Creative Commons Public Domain Dedication waiver (http://creativecommons.org/publicdomain/zero/1.0/) applies to the data made available in this article, unless otherwise stated in a credit line to the data. 
complications $(0.76-25 \%)$ [3, 4] such as infection, hematoma, chronic pain in the donor area, hernia, and residual scarring $[2,5]$. In addition, the quality of autologous bone varies among individuals and age groups, limiting the clinical application [6, 7].

Developments in bone tissue engineering and bone biology have revealed the unique advantages of bone morphogenetic proteins (BMPs) for bone tissue repair. Members of the transforming growth factor superfamily, BMPs, promote bone healing by inducing mesenchymal stem cells to differentiate into osteoblasts $[8,9]$. Two BMPs (recombinant BMP 2 and recombinant BMP 7) have been approved for clinical use by the US Food and Drug Administration (USDA) [10]. Healing rates as high as $92.3 \%$ have been reported in nonunion patients following surgical debridement and fixation with additional BMP treatment [11]. In fact, some clinicians believe that BMP can replace autologous bone transplantation [12, 13]. While a meta-analysis by Dai et al. [14]. concluded that BMPs have not yet surpassed autologous bone transplantation as the optimal treatment for acute tibial fractures and nonunion, the included studies were of small sample size and the subject selection was not restricted to nonunion. Therefore, we conducted a systematic review and meta-analysis of currently available studies to evaluate the advantages and disadvantages of BMP versus autologous bone grafting for the tre e) + of limb long bone nonunion.

\section{Materials and methods} Search strategy

We searched PubMed, Embase, OV , Web pf Science, Cochrane Library, WanFang, CNKI, CBM databases using combinations of the fo wing keywords: "bone morphogenetic protein," "BMP," " genic protein-1," "autologous bone graft ong Kone," "nonunion," and "randomized contr ' $\mathrm{d}$ trials' (last updated on November 30, 20, y). \& gle scholar was also searched to identify pota. lly rele nt literature. In addition, reference lists oniden ied reports were reviewed for other potentialy relevant cudies. Language and publication status a lestricted, and gray literature as well as on ${ }^{\prime} t_{1}$ vere also investigated. All studies were rrefi ly eva aated for the replication of the same data. c. rra woed to define duplicate data included study perio hospital, treatment information, and any additionál inclusion criteria.

\section{Inclusion and exclusion criteria}

Inclusion criteria were as follows: (1) randomized and non-randomized controlled clinical trials of BMP plus autograft for treatment of nonunion without restrictions on country of origin; (2) patients aged 18 years and older with nonunion of tibia, fibula, femur, ulna, radius, or humerus more than 6 months after fracture; (3) treatment with BMP alone or BMP combined with bone graft in the observation group and autologous bone graft in the control group; and (4) publication in English or Chinese. Exclusion criteria were as follows: (1) article type specified as "review," "letter," "conference r port," "case report," or "animal study" and studies wi nout usable data; (2) infection without control; (3) pat. Jgica fracture or congenital bone nonunion; (3) less th months of follow-up, incomplete data, a rrors; 'nd (4) duplicate data from another study.

\section{Data extraction and quality assess int}

Two authors independently racu data from all eligible articles, and any disagre ents were resolved by discussion and conse is among the authors. Information retrieved from each s $y$ included author names, year of publicitio country of origin, study design, methods, numb hostoperative healing rate, infection rate, sec tary operation rate, frequency of excellent/gc ast-treatment limb function, mean healing time, op racio, time, intraoperative blood loss, hospitalization cost, and length of hospital stay. We also ev. ted the potential for bias in all included studies. For i n-randomized trials, the Newcastle-Ottawa Scale DS) was used for bias assessment. For randomized controlled trials, evaluation criteria and methods followed the Cochrane Collaboration proposal. Appraisal criteria included random sequence generation, allocation concealment, blinding of participants and personnel, blinding of outcome assessment, incomplete outcome data, selective reporting, and other sources of bias. Each of these factors was recorded as low risk, unclear risk, or high risk.

\section{Statistical analysis \\ Heterogeneity test and effect value}

A meta-analysis of pooled data was conducted using the Review Manager 5.3 and Stata 12.0 software. Standardized mean differences or weighted mean differences (WMDs) were calculated for continuous variables. Risk ratios (RRs) were calculated for dichotomous variables in each study, and 95\% confidence intervals (CIs) were determined for all effect sizes. Statistical heterogeneity across trials was quantified by the $I^{2}$ statistic according to PRISMA guidelines. A value of $I^{2}$ less than 25\% was considered indicative of homogeneity, and values of $25 \%$, $50 \%$, and $75 \%$ or more were considered indicative of low, moderate, and high heterogeneity, respectively. For homogeneous studies or those with low statistical heterogeneity, the fixed-effects model was used to determine the overall RR or WMD. Otherwise, the random-effects model was used. Sensitivity analyses were conducted by removing each study individually to assess 
heterogeneity and robustness of the pooled results. Datasets causing significant changes in pooled results when removed were analyzed further to assess the reason. We then judged the results for stability and strength. If the heterogeneity was too large to analyze, descriptive analyses are presented.

\section{Publication bias}

We assessed potential publication bias using Begg and Egger tests. All tests were two-tailed, and a $P<0.05$ was considered significant.

\section{Results}

\section{Search results}

A total of 511 publications were selected from the initial search, of which 143 were duplicates and 256 did not match our inclusion criteria according to title and abstract assessment. No data were obtained from the gray literature or ongoing trial searches (we received no answers from the authors we contacted). Of the remaining 112 studies retrieved, 103 did not meet the inclusion criteria after the full-article assessment. Finally, 5 randomized controlled trials (RCTs) [15-19] and 4 nonrandomized controlled trials [20-23] were included in the systematic review and meta-analysis, most of which were small sample size studies of 30-124 cases, with a total of 655 nonunion cases. These 9 studies [15-23] reported on 11 trials as one (Hackl et al. [23]) reported 3 clinical trials. The observation group was treated with BMP plus autologous bone in 5 studies, BMP alors in 2 studies, and BMP combined with natural inorg hic bone in one study. In the ninth study, the observatio roup consisted of 18 cases receiving BMP alone and 8 es receiving BMP plus autologous bone gra. g. All control groups received autologous bone grats, an 11 patients in both groups underwent mecha ical fixatio, (intramedullary nail, plate, screw, minima invasiye stabilization system, external fixation, etc. The ature search and selection process are illy strated Fig. 1.

\section{Study characteristic.}

The primary $\mathrm{c}$ is of the 9 selected studies are summarized in $\mathrm{T}$ a 1 . According to the Cochrane Collaboration ${ }^{-1}$ of Eias Tool, the quality of 4 RCTs was acceptable (Fig. $)$. The non-randomized controlled trials were also considered to be of high quality according to thu ewcastle-Ottawa Scale (Table 2).

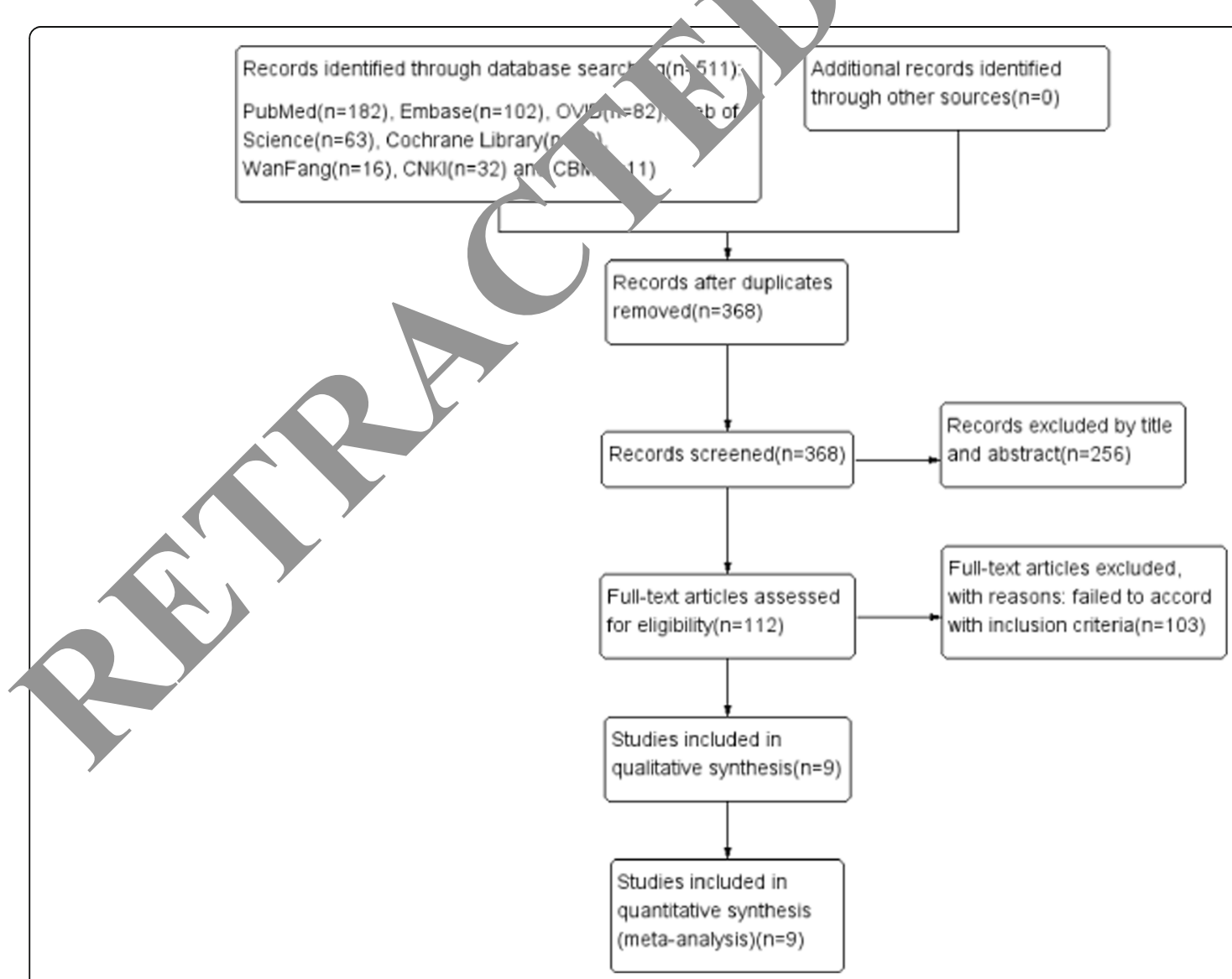

Fig. 1 PRISMA flowchart of the study selection process 
Table 1 Summary of study and patient characteristics

\begin{tabular}{|c|c|c|c|c|c|c|c|c|c|}
\hline Study & Study type & Country & Intervention & Case & Age, years & $M / F$ & $\begin{array}{l}\text { Nonunion time } \\
\text { (months) }\end{array}$ & $\begin{array}{l}\text { Follow-up } \\
\text { (months) }\end{array}$ & Outcome \\
\hline Cook [15] & $\mathrm{RCT}$ & USA & $\begin{array}{l}\text { BMP } \\
\text { Autologous bone }\end{array}$ & $\begin{array}{l}14 \\
16\end{array}$ & $\begin{array}{l}- \\
-\end{array}$ & $\begin{array}{l}23 \\
7\end{array}$ & 27.2 & $>9$ & $(1),(2)$ \\
\hline Chen et al. [19] & $\mathrm{RCT}$ & China & $\begin{array}{l}\text { BMP + inorganic bone } \\
\text { Autologous bone }\end{array}$ & $\begin{array}{l}20 \\
30\end{array}$ & $\begin{array}{l}35 \\
35\end{array}$ & - & 8.5 & $13.9(8-60)$ & \\
\hline Friedlaender et al. [16] & $\mathrm{RCT}$ & USA & $\begin{array}{l}\text { BMP + autologous bone } \\
\text { Autologous bone }\end{array}$ & $\begin{array}{l}63 \\
61\end{array}$ & $\begin{array}{l}38 \\
34\end{array}$ & $\begin{array}{l}88 \\
34\end{array}$ & 17 & 24 & \\
\hline Zimmermann et al. [20] & $\mathrm{n}-\mathrm{RCT}$ & Germany & $\begin{array}{l}\text { BMP + autologous bone } \\
\text { Autologous bone }\end{array}$ & $\begin{array}{l}26 \\
82\end{array}$ & $\begin{array}{l}51 \\
44\end{array}$ & $\begin{array}{l}82 \\
26\end{array}$ & $\begin{array}{l}10 \\
11\end{array}$ & & \\
\hline Tressler et al. [21] & $\mathrm{n}-\mathrm{RCT}$ & USA & $\begin{array}{l}\text { BMP } \\
\text { Autologous bone }\end{array}$ & $\begin{array}{l}19 \\
74\end{array}$ & $\begin{array}{l}45.11 \\
41.69\end{array}$ & $\begin{array}{l}57 \\
36\end{array}$ & $>6$ & & \\
\hline von Ruden et al. [17] & RCT & Germany & $\begin{array}{l}\text { BMP + autologous bone } \\
\text { Autologous bone }\end{array}$ & $\begin{array}{l}24 \\
25\end{array}$ & $\begin{array}{l}43 \\
45\end{array}$ & $\begin{array}{l}38 \\
11\end{array}$ & 11 & & $(1),(3)$ \\
\hline Yin et al. [22] & $\mathrm{n}-\mathrm{RCT}$ & China & $\begin{array}{l}\text { BMP + autologous bone } \\
\text { Autologous bone }\end{array}$ & $\begin{array}{l}26 \\
21\end{array}$ & $\begin{array}{l}38 \\
39\end{array}$ & $\begin{array}{l}35 \\
12\end{array}$ & & & $(1),(3),(4)$ \\
\hline Hackl et al. [23] & $\mathrm{n}-\mathrm{RCT}$ & Germany & $\begin{array}{l}\text { BMP + autologous bone } \\
\text { Autologous bone }\end{array}$ & $\begin{array}{l}62 \\
50\end{array}$ & - & & & $>12$ & $(1),(4)$ \\
\hline Humerus & & & & $13 / 9$ & $49.0 / 51$ & & & & \\
\hline Femoral & & & & $28 / 13$ & 55.211 & & & & \\
\hline Tibia & & & & $21 / 28$ & $\begin{array}{l}51.6 \\
42.3\end{array}$ & & $10.3 \pm 2.6$ & & \\
\hline Liu et al. [18] & $\mathrm{RCT}$ & China & $\begin{array}{l}\text { BMP + autologous bone } \\
\text { Autologous bone }\end{array}$ & & $\begin{array}{l}42.25 \\
41.57\end{array}$ & $\begin{array}{l}26 \\
16\end{array}$ & - & $6-24$ & $(1),(3),(4),(5)$ \\
\hline
\end{tabular}

$R C T$ randomized controlled trial, $n-R C T$ non-randomized controlled trial, $B M P$ bont rphoc netic protein

(1) Postoperative healing rate, (2) postoperative infection rate, (3) excelle it and goo a f limb function, (4) the mean healing time, (5) secondary operation rate, (6) operation time, (7) intraoperative blood loss, (8) hospital stay d ( 9 ' the hosp alization cost

\section{Results of meta-analysis \\ Postoperative healing rate}

Postoperative healing rate was evalua ed in nine scudies [15-23]. The meta-analysis revealed o significant difference in the final healing outcome be on the observation and control groups $(\mathrm{RR}=00,95 \%$ Cl 0.94-1.07, $P$ $=0.89$, Fig. 3$)$ with low heterogen $/$, among studies $(P$ $\left.=0.07, I^{2}=42 \%\right)$. In th nsitivity analysis, removal of Zimmermann et al. ? $s$ inificantly reduced the study heterogeneity $\left(I^{2}-0 \%,=0.54\right)$ but had only modest effects on the led res is $(\mathrm{RR}=0.97,95 \% \mathrm{CI} 0.90-$ $1.04, P=0.34$. A vsis of the causes of heterogeneity revealed hat all case in Zimmermann et al. (2009) had a previo b. tor of failed autologous bone graft repair, and MP used as an alternative treatment. It is posble lat suon patients demonstrate better BMP respons. ess nan patients without previous bone graft repa There were also fewer patients in the BMP group than the control group, which may have added heterogeneity to the pooled sample.

Five studies [16-18, 22, 23] used BMP combined with autologous bone transplantation in the observation group and autologous bone transplantation alone in the control group. There was no statistical heterogeneity among the groups $\left(I^{2}=0 \%, P=0.42\right)$, so the fixed-effect model was adopted. The meta-analysis revealed no significant difference in the postoperative healing rate between the observation and control groups $(R R=0.99$, 95\%CI 0.92-1.07, $P=0.86$, Fig. 4a). Only two studies $[15,21]$ used BMP alone in the observation group, but there was no significant heterogeneity so a fixed-effects model was applied $\left(I^{2}=0 \%, P=0.48\right)$. The pooled results indicated no significant difference in 1 postoperative healing rate between the two groups $(R R=0.84$, 95\%CI 0.67-1.05, $P=0.13$, Fig. 4b).

Five studies $[15,16,19,20,23]$ examined the nonunion of the tibia. There was no significant difference in postoperative healing rate between the observation group (BMP or BMP combined with autologous bone transplantation) and the control group ( $R R=1.01$, 95\%CI $0.90-1.13, P=0.92$, Fig. 5) but with high heterogeneity between the groups $\left(I^{2}=65 \%, P=0.02\right)$. A sensitivity analysis showed that the heterogeneity decreased substantially after excluding Zimmermann et al. [20] $\left(I^{2}=0 \%, P=0.52\right)$, while the outcome comparison was not significantly altered $(R R=0.95$, 95\% CI $0.87-1.03, P=0.21$ ).

In conclusion, there were no significant differences in the postoperative rate between the BMP and control groups. Further, the combination of autogenous bone with BMP did not alter this result. In addition, the outcome did not differ between the groups for nonunion of 


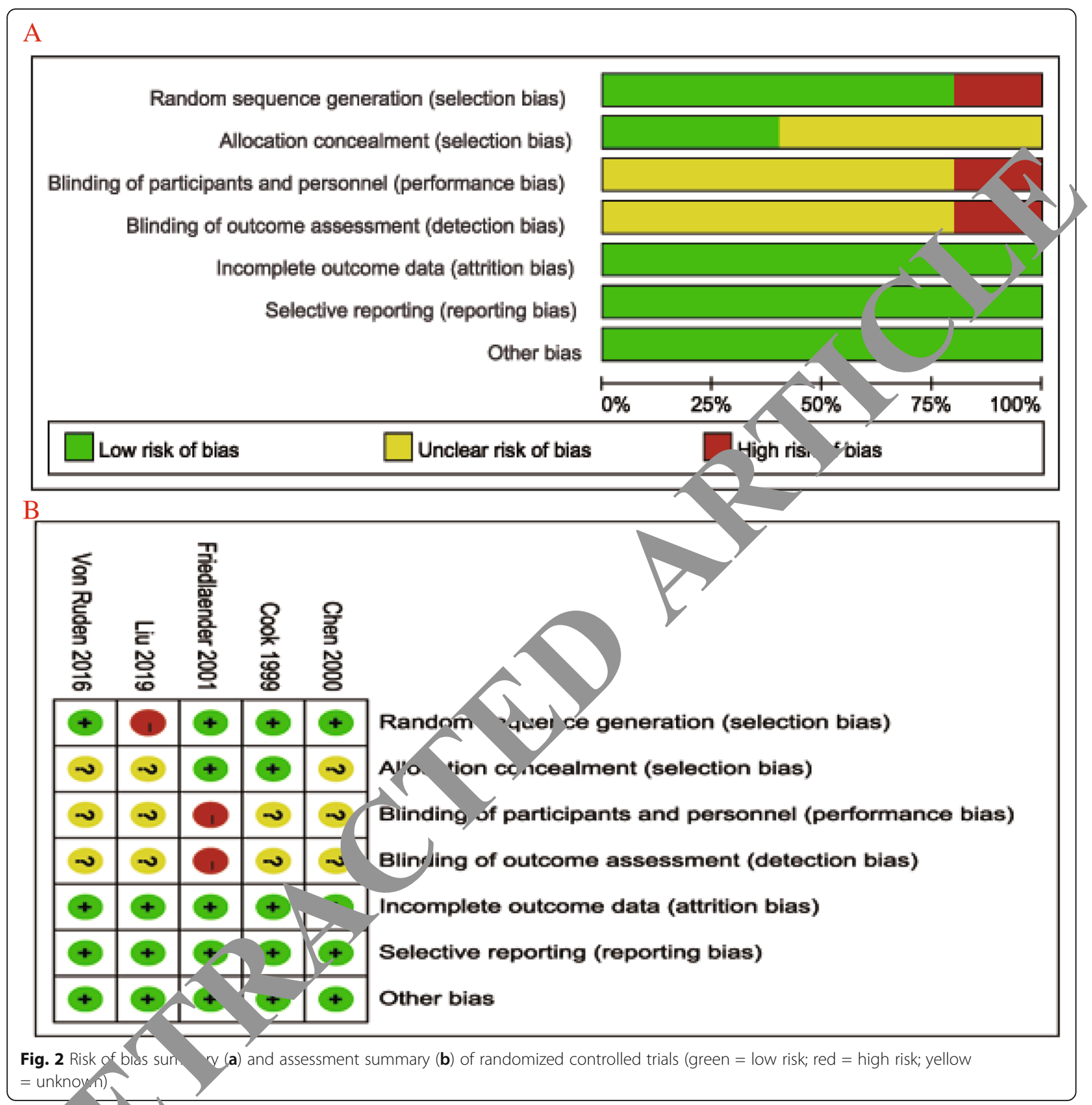

Table 2 Quality evaluation of non-randomized controlled trials (NOS)

\begin{tabular}{|c|c|c|c|c|c|c|c|c|c|}
\hline Study & First item & Second item & Third item & Fourth Item & Fifth item & Sixth item & Seventh item & Eighth item & Scores \\
\hline Zimmermann et al. [20] & 1 & 1 & 0 & 1 & 2 & 1 & 1 & 1 & 8 \\
\hline Tressler et al. [21] & 1 & 1 & 1 & 1 & 2 & 1 & 1 & 1 & 9 \\
\hline Yin et al. [22] & 1 & 1 & 0 & 1 & 2 & 1 & 1 & 1 & 8 \\
\hline Hackl et al. [23] & 1 & 1 & 0 & 1 & 2 & 1 & 1 & 1 & 8 \\
\hline
\end{tabular}




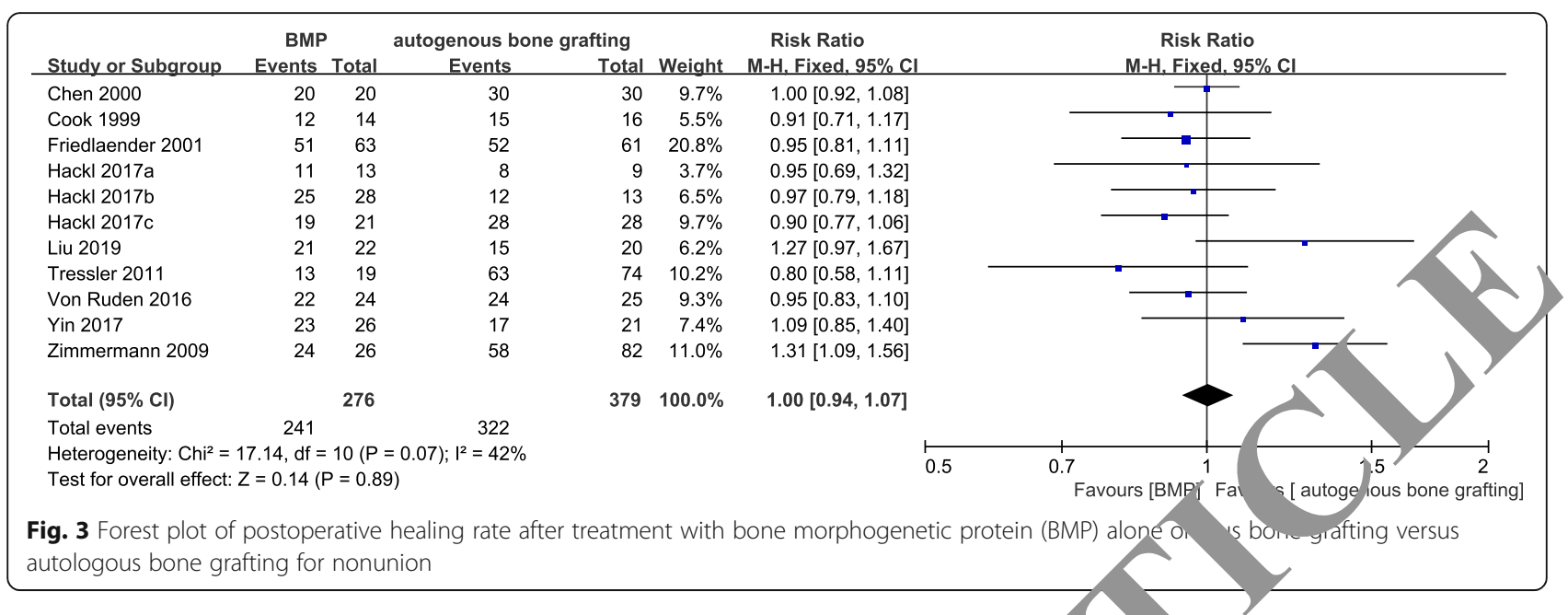

any long bone and nonunion specifically in the tibia. Sensitivity analysis also showed that the results of the meta-analysis were stable.

\section{Postoperative infection rate}

Four studies $[15,16,20,21]$ provided data on postoperative infection rate, including 116 patients in the BMP group and 222 in the control group. There was no statistical heterogeneity $\left(I^{2}=0 \%, P=0.83\right)$ and no signi licant difference in the outcome between the groups 0.96, 95\%CI 0.53-1.77, $P=0.91$, Fig. 6).

\section{Excellent and good rate of limb function}

Postoperative excellent/good postope ative limb function rate was documented in 4 articles $\left[\begin{array}{lll}1 & 19,2\end{array}\right]$. A fixed- effects model yas . plied because no statistical heterogeneity was to $d$ o $0 \%, P=0.68$ ). There was a significant differe in the outcome between the observation an ntrol group ( $R R=1.18,95 \% C I 1.01-1.39$, $P=0.04$, iis. 7 , The Chen et al. [19] study treated the observation group using BMP plus natural inorganic Do. which may have a disproportion influence on the o tcome; however, removing this study had little ct on the pooled results $(\mathrm{RR}=1.22,95 \% \mathrm{CI} 1.01-$ 1.4 $P=0.04)$.

\section{The mean healing time}

Three articles [18, 22, 23] with 201 patients reported data on the mean healing time. A fixed-effects model was applied because low heterogeneity was found among

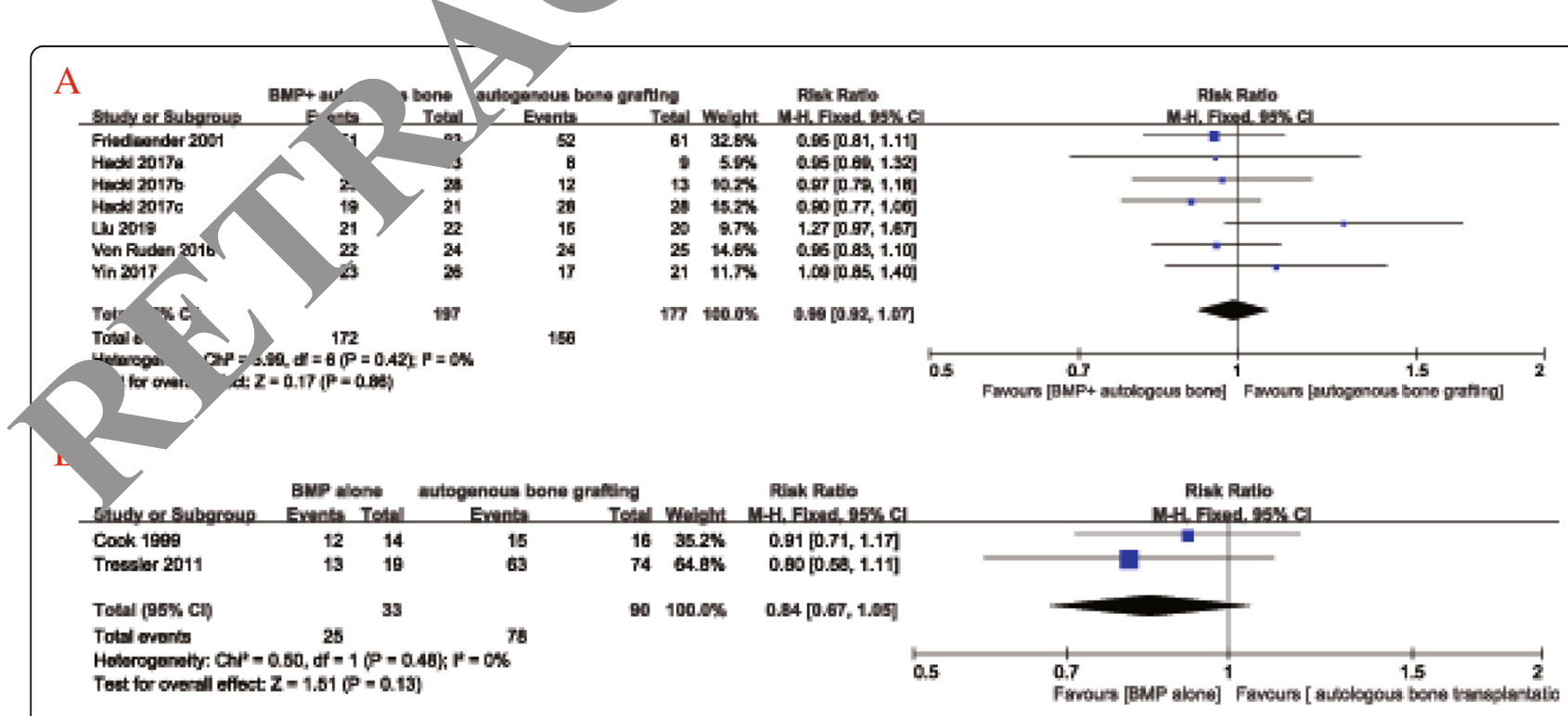

Fig. 4 Forest plot of postoperative healing rate after BMP combined with bone grafting (a) and BMP alone (b) versus autologous bone grafting alone for nonunion 


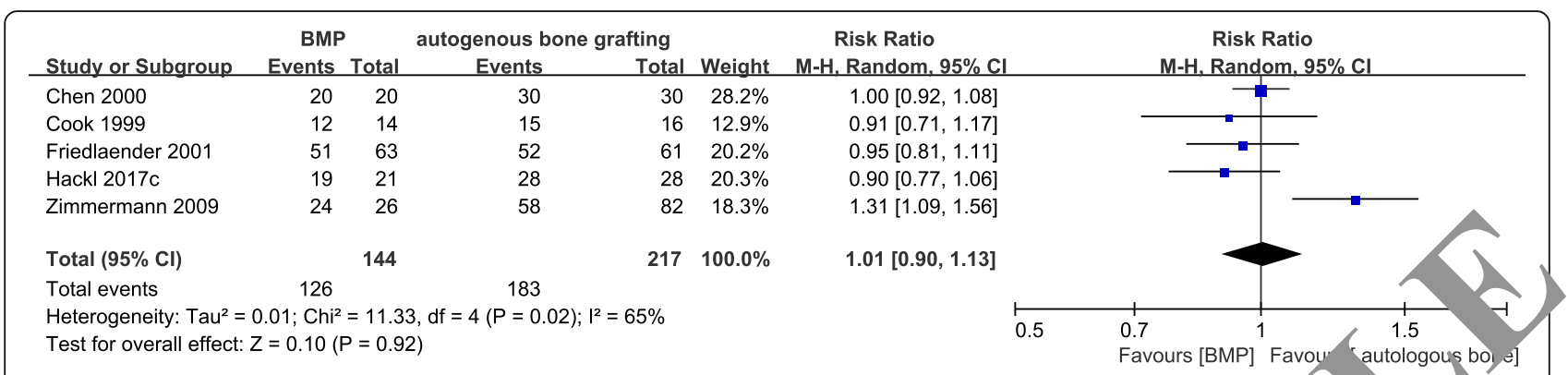

Fig. 5 Forest plot of postoperative healing rate after BMP or BMP combined with autologous bone versus autologous bond grat tibial nonunion

the studies $\left(I^{2}=21 \%, P=0.28\right)$. Mean healing time was significantly shorter in the observation group compared to the control group (WMD $=-1.27$, $95 \%$ CI -1.67 to $-0.88, P<0.00001$, Fig. 8 ).

\section{Secondary operation rate}

Three studies $[16,18,20]$ provided data on secondary operation rate with moderate heterogeneity $\left(I^{2}=56 \%, P\right.$ $=0.10)$ and no significant difference in the outcome between the groups $(\mathrm{RR}=0.55,95 \% \mathrm{CI} 0.19-1.64, P=0.29$, Fig. 9).

\section{Operation time and intraoperative blood loss}

Two articles reported the operation time and juraop tive blood loss. Descriptive analyses aro resente, because the BMP intervention differed betwe the 2 studies. In Yin et al. [22], the BMP ombined wi,, $\mathrm{nu}$ tologous bone graft group included 6 patients and the control group 21 cases. Operation til was ignificantly shorter in the observation gr nan in the control group (70.96 \pm 13.34 vs. 101.6$\rangle \pm>8 \mathrm{~min} ; P<0.01$ ). Tressler et al. [21] also pare the operation time as well as the intraope ive lond loss between 19 cases receiving BMP al The operation a was as an significantly shorter in the observation gioup mpared to the control group (168.9 \pm 86.5 yo. $257.9 \pm 90$ min, $P<0.01)$. The intraoperative blood loss was also lower th servation group $(331.6 \pm 357.2$ vs. $554.6-447.8, P=0.02)$.

Hospital stay and the hospit. ation cost

One study eacb re $\mathrm{P}_{\mathrm{P}}$ ted the length of hospital stay and hospitalization sler et al. [21] found a shorter hospital stay in th. observation group, although the difference $d+$ reacin significance $(3.2 \pm 2.6$ vs. $3.8 \pm 2.5$ days, $P=(37)$, wile Yin et al. [22] found a higher average hospitalization cost in the observation group com$\mathrm{Pa}$ to the control group $(2.65 \pm 0.34$ vs. $2.14 \pm 0.35$ in units $f$ ten thousand Yuan, $P<0.01$ ).

\section{Puolication bias}

The large sample sizes of some pooled outcomes, such as postoperative healing rate, allowed for the application of Begg's test and Egger's test for the analysis of publication bias. No significant bias was found across studies by either test (Begg test, $P=0.592$, Fig. 10a; Egger test, $P=$ 0.863, Fig. 10b).

\section{Sensitivity analysis}

Sensitivity analysis indicated our current data was relatively steady and credible (Fig. 11).

\section{Discussion}

Nonunion of long bone fracture is associated with a greater risk of complications and poor long-term

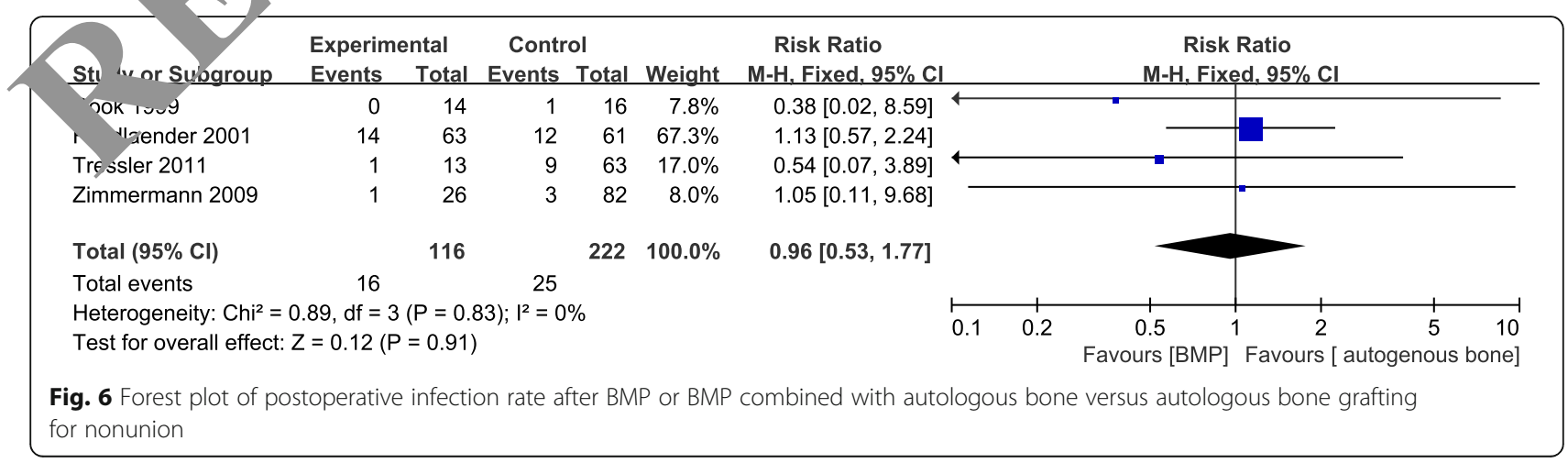




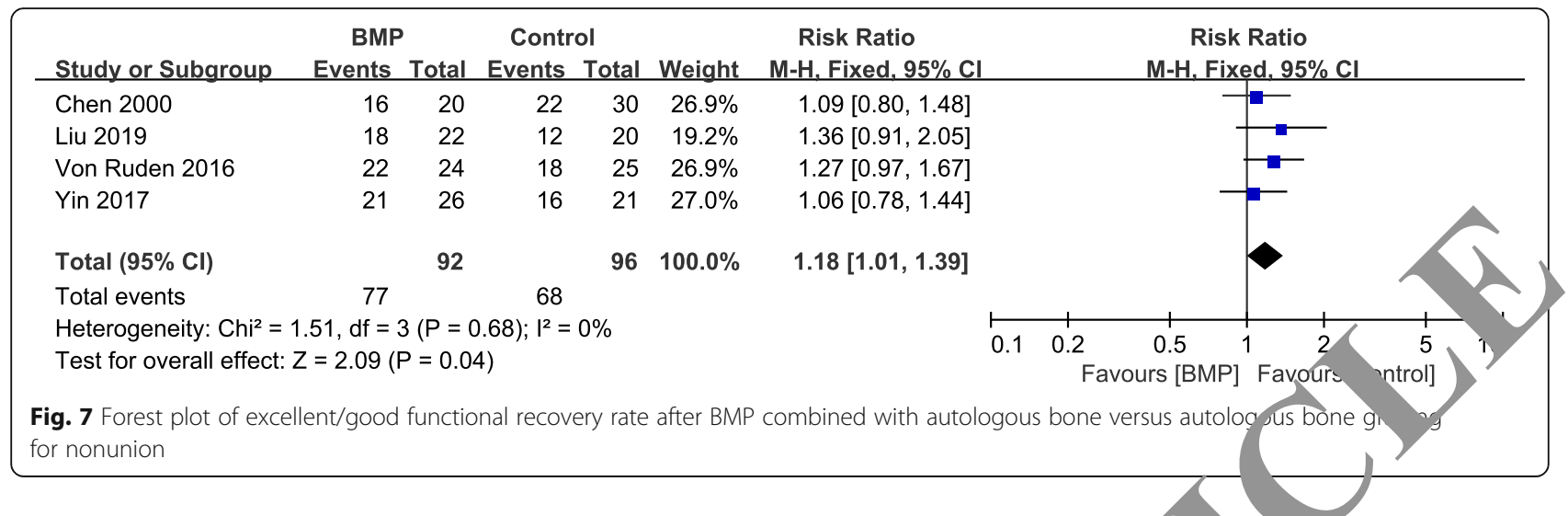

prognosis [24]. Numerous factors influence fracture healing, including fracture type, fracture site, degree of surgical dissection, fracture end stability, infection, poor mechanical fixation, inadequate blood supply, malnutrition, and chronic disease [6, 25]. Most fractures heal within 20 weeks, and nonunion is defined as incomplete healing within 6 months [26]. Bone repair can be induced by local biological stimulation at the fracture site when healing is delayed or nonunion occurs. At present, autologous bone grafting remains the "gold standard" [1, $2,20,22]$ by which other treatment options are compared. However, autologous bone harvesting can r sult in chronic pain, scarring at the donor site, and ey se ious complications such as vascular injury, ne $v \mathrm{v}$ in and deep infection [3]. In addition, there a limits y the size, shape, and quantity of autologous bont at can be harvested for grafting. In additio, there are aifferences in the quality of autologous bone among individuals and age groups [6, 7]. in tance, the elderly generally have poor ne for grafting while patients with nonunion may havery retic factors that prevent bone healing e do nor site as well as the primary fracture sit 6$]$.

Bone morphog rintic poteins constitute a family of soluble bone $\mathrm{r}_{\mu} \quad \mathrm{x}_{\mathrm{x}}$ glycop $\mathrm{p}$ teins that induce migration, proliferation, and "erentiation of undifferentiated mesenchymal stem cyls to form osteoblasts and chondroblasts. These difierentia cells then synthesize collagen to form calr it bone $t$ ssue, promoting bone tissue repair and angiogo cis [9]. Past studies have shown that BMPS t only promote nonunion healing, but also reduce fo and pain $[7,12,13,16,27,28]$. In fact, healing ra of over $90 \%$ have been reported in nonunion usirg BMP treatment $[11,13]$. However, several studies, ave concluded that combining BMP with bone transplantation does not improve outcome an nly increases the cost of treatment [29, 30]. For instanc Hackl et al. [23]. concluded that autologous bone fting alone is equally effective and less costly than combined recombinant BMP and autologous bone grafting for aseptic nonunion of the humerus, femur, or tibia. Others have speculated that the development of BMP treatment may be driven largely by potential profits rather than improved efficacy and safety given the huge market potential of bone graft substitutes $[24,26,30]$. Previous studies on BMP efficacy are difficult to compare because of the differences in the study design, inclusion criteria, and types of nonunion. Only two meta-analyses have evaluated BMP for nonunion patients, with discrepant conclusions. Schenker et al. found a faster healing rate in the BMP treatment group, while Dai et al. [14] found no significant difference in healing rate, secondary surgery rate, or infection rate between the BMP and control groups. However, these

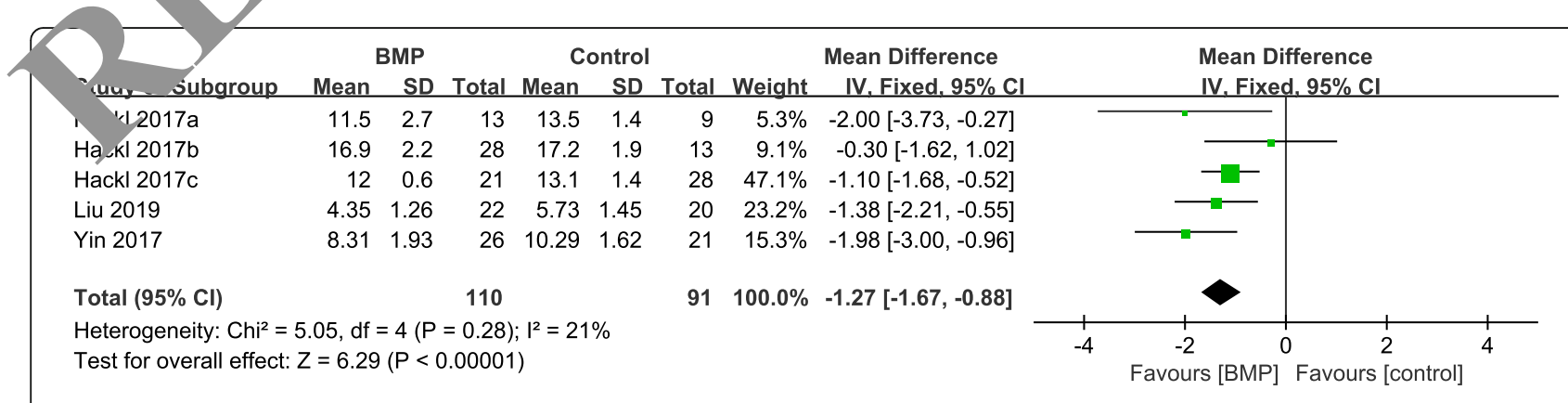

Fig. 8 Forest plot of mean healing time after BMP combined with autologous bone versus autologous bone grafting for nonunion 


\begin{tabular}{|c|c|c|c|c|c|c|c|}
\hline Study or Subgroup & $\begin{array}{l}\text { BMP } \\
\text { Events }\end{array}$ & Total & $\begin{array}{l}\text { Contro } \\
\text { Events }\end{array}$ & $\begin{array}{l}\text { ol } \\
\text { Total }\end{array}$ & Weight & $\begin{array}{l}\text { Risk Ratio } \\
\text { M-H, Random, } 95 \% \text { CI }\end{array}$ & $\begin{array}{c}\text { Risk Ratio } \\
\text { M-H, Random, } 95 \% \mathrm{Cl} \\
\end{array}$ \\
\hline Friedlaender 2001 & 3 & 83 & 6 & 61 & $31.1 \%$ & $0.37[0.10,1.41]$ & \begin{tabular}{l|l}
- \\
\end{tabular} \\
\hline Liu 2019 & 1 & 22 & 5 & 20 & $18.9 \%$ & $0.18[0.02,1.43]$ & \\
\hline Zimmermann 2009 & 9 & 26 & 26 & 82 & $50.0 \%$ & $1.09[0.59,2.02]$ & \\
\hline Total $(95 \% \mathrm{Cl})$ & & 131 & & 163 & $100.0 \%$ & $0.55[0.19,1.64]$ & \\
\hline Total events & 13 & & 37 & & & & \\
\hline $\begin{array}{l}\text { Heterogeneity: } \mathrm{Tau}^{2}= \\
\text { Test for overall effect }\end{array}$ & $\begin{array}{l}0.51 ; \mathrm{Chi}^{2} \\
Z=1.07(\mathrm{~F}\end{array}$ & $\begin{array}{l}=4.55 \\
=0.2\end{array}$ & df $=2(P$ & $=0.10$ & $0) ; I^{2}=56 \%$ & & $\begin{array}{lllll}0.1 & 0.2 & 0.5 & 1 & 2 \\
& & \text { Favours [BMP] } & \text { Favours }[\text { [co }\end{array}$ \\
\hline
\end{tabular}

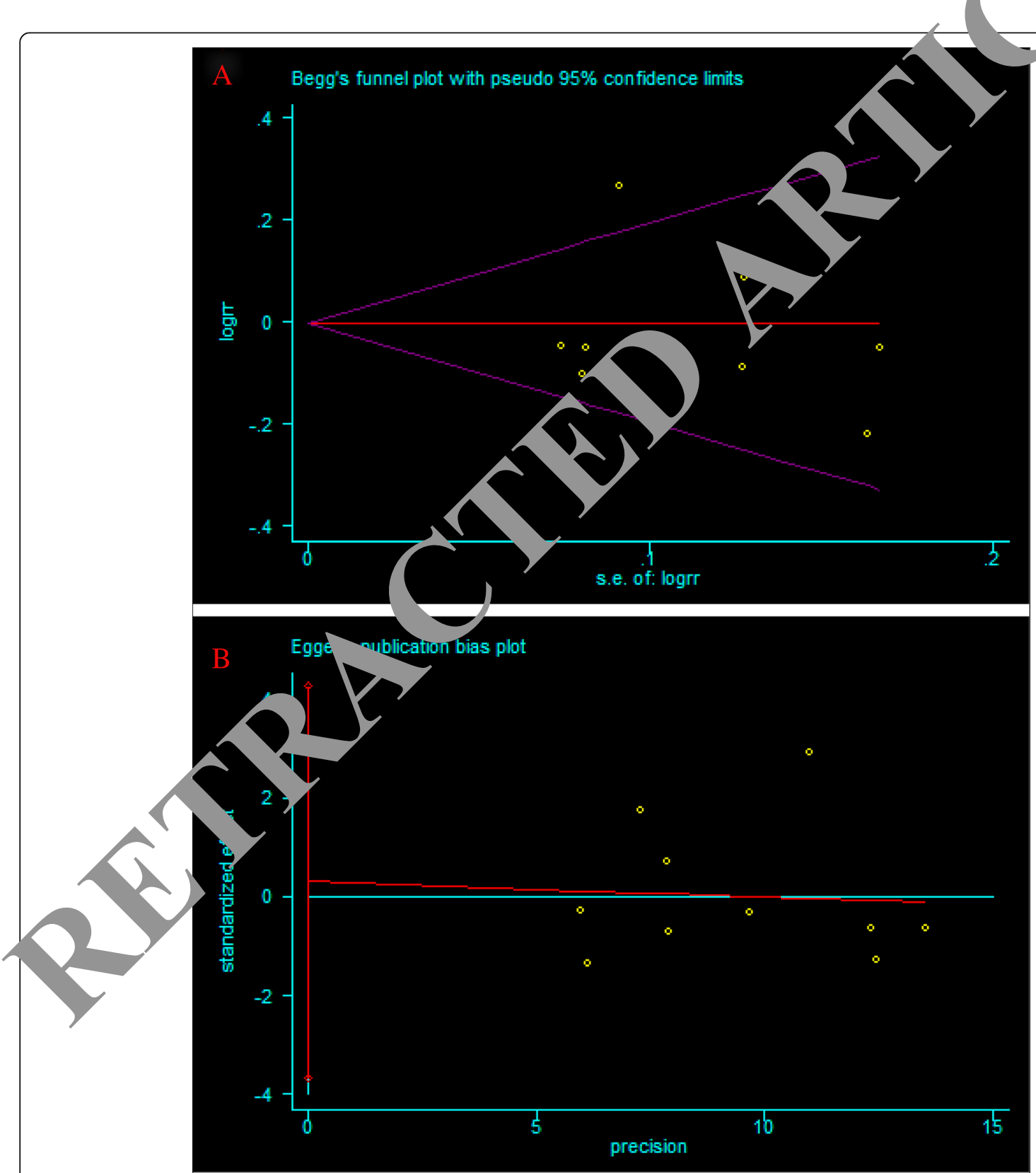

Fig. 10 Publication bias for postoperative healing rate after BMP or BMP combined with autologous bone versus autologous bone grafting for nonunion. a Begg's funnel plots. b Egger's funnel plots 


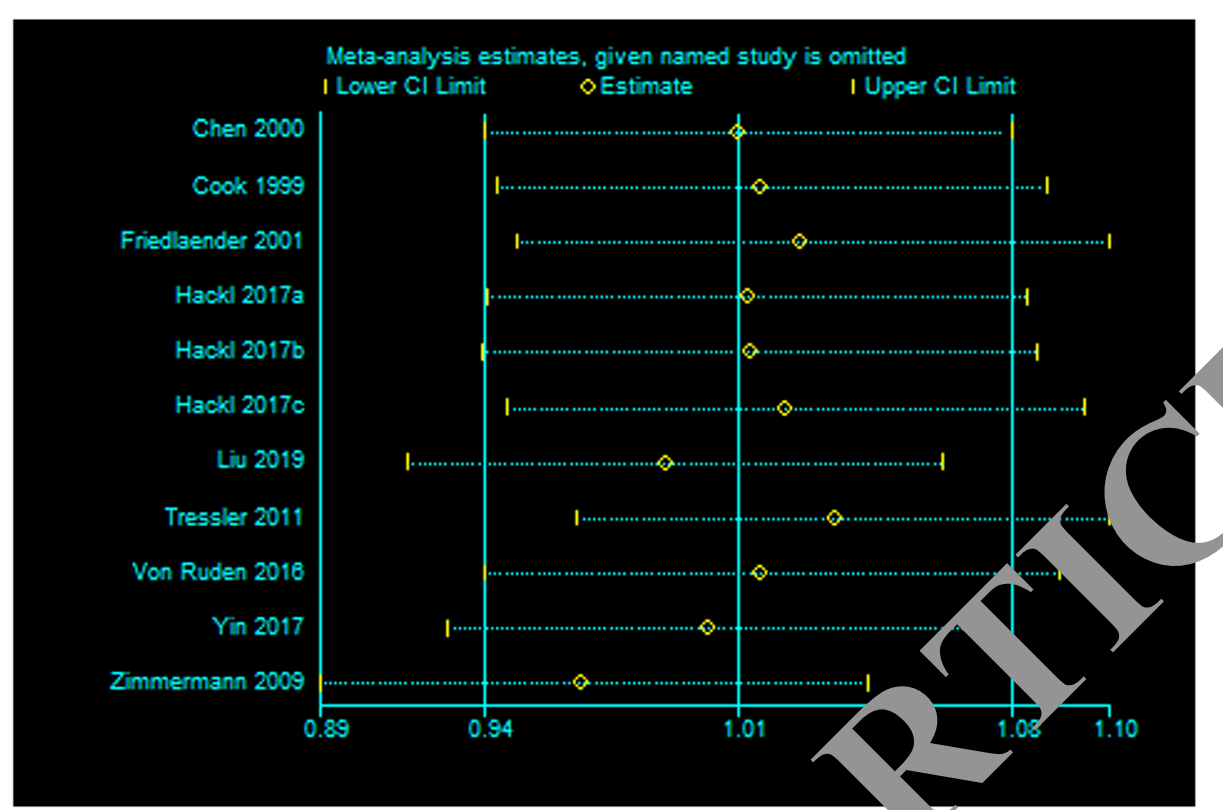

Fig. 11 Sensitivity analysis of postoperative healing rate after BMP or BMP combined v for nonunion

conclusions were limited by the small sample sizes and poor quality of the included studies.

The results of this meta-analysis are that (1) BM to not significantly improve the final extent of bealing, ?) addition of BMP to autologous bone transp tation $\mathrm{re}$ duces fracture healing time, although treatmen cost is higher; (3) BMP alone can reduce ope ation time a. Id intraoperative blood loss; (4) additior of BMP improves postoperative function; and (5) add of BMP does not influence the infection rate rate or secondary surgery. The study by Yin et al. [2 $21 \mathrm{~d}$ no increase in operation time when ing $\mathrm{KM}$ treatment during bone grafting. How $r$, not of the studies did not provide specific cucrip ns of the operation time and procedure, so faffect or ding BMP treatment is still uncertain.

It has been reporte, that the bone induction effect of BMP is t_upe vior to autologous bone transplantation $\left[16{ }^{-1}, 31\right.$, d hat BMP actually results in slower bone oalir rate than autologous bone grafting alone (alth. on twe difference was not statistically significant). How cr, a multitude of factors ultimately contribute to the outcome, and different conditions require specific treatments, all of which may obscure the benefits of BMP. Nonetheless, BMP treatment was found to benefit certain outcome variables in this meta-analysis, suggesting BMP as a viable alternative or safe adjuvant for autologous bone grafts. Due to high cost, however, early studies did not recommend BMPs as a routine treatment for bone non-attachment. In contrast, recent cost- offect eness studies support the use of BMPs in the tyent of persistent nonunion [30, 32-34]. Early use of)BMPs may be a cost-effective strategy for treating severe cases of bone and soft tissue damage given the costs of prolonged hospitalization, medication, repeated surgical failure, and disability [30, 32-34].

The following limitations of this meta-analysis should be acknowledged. First, the pooled sample included non-randomized controlled studies, some of which did not specify group allocation or blinding, thereby introducing a risk of bias. Second, many of the studies were of small sample size. Third, long bone nonunion most often occurs in the tibia, and more than half of the cases included in the sample were patients with tibial nonunion. Therefore, the relevance of our conclusions to other long bones is less certain. Fourth, some of the studies did not specifically describe the follow-up time, so some postoperative complications and secondary operations may not have been reported. Fifth, many independent variables can affect fracture nonunion (e.g., fracture type, mechanical fixation, amount and mode of autologous bone transplantation, dose and type of BMP). Additional multicenter randomized studies are needed to control for preexisting factors associated with fracture nonunion.

In conclusion, BMP alone can improve postoperative function, shorten operation time, and reduce intraoperative blood loss in cases of long bone nonunion. Therefore, BMP may reduce done-site complications from bone extraction and provide a new treatment option for 
patients with poor donor bone quality or poor surgical tolerance. Bone morphogenetic protein combined with autologous bone transplantation also appears to accelerate fracture healing. However, the current evidence does not support the widespread promotion and application of BMP for improved outcomes. Large-scale clinical studies are still needed to comprehensively analyze its efficacy and economic benefits.

\section{Abbreviations}

BMP: Bone morphogenetic protein; CNKI: China Biomedical Literature Database; NOS: Newcastle-Ottawa Scale; WMD: Weighted mean difference; RR: Risk ratio; RCT: Randomized controlled trial; Cl: Confidence interval

\section{Acknowledgements}

None.

\section{Authors' contributions}

All authors listed have made contributions to the meta-analysis. YQZ and XC designed the study. YQZ, XC, JC, and HLT participated in performing the review and collecting the data. YQZ, XC, and YJD took part in analyzing the data. YQZ and XC wrote and revised the manuscript. All authors read and approved the final manuscript.

\section{Funding}

This research received no external funding

\section{Availability of data and materials}

The datasets generated during and/or analyzed during the current study are available from the corresponding author on reasonable request.

\section{Ethics approval and consent to participate}

This study dealt with published data only, no ethical approval was

Consent for publication

Not applicable.

\section{Competing interests}

The authors declare that they have no competing terests.

Received: 21 May 2020 Accepted: 16 Ju't 2020

Published online: 29 July 2020

\section{References}

1. Sen MK, Miclau T. Autolo us ilia crest bo, e graft: should it still be the gold standard for treating , ury. 2007;38(Suppl 1):S75-80.

2. Dimitriou R, Matali takis Gl, A vles, AG, Kanakaris NK, Giannoudis PV. Complications $f$ or. ing autolog is bone graft harvesting from the iliac crest and usin, the systematic review. Injury. 2011;42(Suppl 2):S3-15.

3. Arrington Smith $W$, mbers $H G$, Bucknell AL, Dabino NA Comp' ations of iliac crest bone graft harvesting. Clin Orthop Relat Res. 1996, or

4. L Baron Vivon JP, Maman P, Volpi R, Flecher X. Can the reamer/ tor/asp. or system replace anterior iliac crest grafting when treating or hane nonunion? Orthop Traumatol Surg Res. 2019;105(3):529-33. Sariali E, Khiami F, Pascal-Mousselard H, Catonne Y. Iliac crest graft harvesting complications: a case of liver herniation. Orthop Tro umatol Surg Res. 2010;96(5):593-6.

6. Dimitriou R, Kanakaris N, Soucacos PN, Giannoudis PV. Genetic predisposition to non-union: evidence today. Injury. 2013:44(Suppl 1):S50-3.

7. Singh R, Bleibleh S, Kanakaris NK, Giannoudis PV. Upper limb nonunions treated with BMP-7: efficacy and clinical results. Injury. 2016; 47(Suppl 6):S33-9.

8. Hreha J, Krell ES, Bibbo C. Role of recombinant human bone morphogenetic protein-2 on hindfoot arthrodesis. Foot Ankle Clin. 2016 21(4):793-802.

9. Marupanthorn K, Tantrawatpan C, Kheolamai P, Tantikanlayaporn D, Manochantr S. Bone morphogenetic protein-2 enhances the osteogenic differentiation capacity of mesenchymal stromal cells derived from human bone marrow and umbilical cord. Int J Mol Med. 2017:39(3):654-62.

10. Barcak EA, Beebe MJ. Bone morphogenetic protein: is there still a role in orthopedic trauma in 2017? Orthop Clin North Am. 2017;48(3):301-9.

11. Dimitriou R, Dahabreh Z, Katsoulis E, Matthews SJ, Branfoot T, Giannoudis PV. Application of recombinant BMP-7 on persistent upper and lower limb non-unions. Injury. 2005;36(Suppl 4):S51-9.

12. Hissnauer TN, Stiel N, Babin K, Rupprecht M, Ridderbusch K, Ruege JM Stuecker R, Spiro AS. Recombinant human bone morphogenet proliein-2 (rhBMP-2) for the treatment of nonunion of the femur in chida adolescents: a retrospective analysis. Biomed Res Int. 2017;2017:30

13. Kanakaris NK, Calori GM, Verdonk R, Burssens P, Biase Po, Capanna R, Vangosa LB, Cherubino P, Baldo F, Ristiniemi J, Konta Gianno dis PV. Application of BMP-7 to tibial non-unions: a 3-y mult ter ey perience. Injury. 2008;39(Suppl 2):S83-90.

14. Dai JZ, Li L, Jiang CY, Wang CY, Chen H, Cl YM. Bone morphogenetic protein for the healing of tibial fractu'e: a $n$-analysis of randomized controlled trials. PLoS One. 2015;18 014

15. Cook SD. Preclinical and clinica'cralua of osteogenic protein-1 (BMP-7) in bony sites. Orthopedics. 1 9:22(7):669-

16. Friedlaender GE, Perry CP Cou Cook SD, Cierny G, Muschler GF, Zych GA, Calhoun JH, LaForte Ay, Yin S. teogenic protein-1 (bone morphogenetic prow in the tre ment of tibial nonunions. J Bone Joint Surg Am 83-A al. $2($ 1:1(Pt 2):S151-8.

17. von Ruden C, Mo sur... Aierholzer C, Hackl S, Gradinger FL, Woltmann A, Buhre iederichs J. The missing effect of human recomb t bone mo, nogenetic proteins BMP-2 and BMP-7 in surgical treatmen On forearm nonunion. Injury. 2016;47(4):919-24.

18. Liu D, Bai Zhuan,g X. Comparison of effect of two different methods of postoperati e bone nonunion. Medical Journal of National Defending rces in Scuthwest China. 2019;29(10):1008-10.

19. $\mathrm{G}$, Yang J, Xu H. The application of NNB/BMP complex in the treatment of iunited-tibia fracture. Orthopedic Journal of China. 2000;7(8):758-61. 7i nmermann G, Wagner C, Schmeckenbecher K, Wentzensen A, Moghaddam A. Treatment of tibial shaft non-unions: bone morphogenetic proteins versus autologous bone graft. Injury. 2009;40(Suppl 3):S50-3.

21. Tressler MA, Richards JE, Sofianos D, Comrie FK, Kregor PJ, Obremskey WT. Bone morphogenetic protein-2 compared to autologous iliac crest bone graft in the treatment of long bone nonunion. Orthopedics. 2011;34(12): e877-84.

22. Yin $\mathrm{H}$, Wang $\mathrm{H}$, Huang $\mathrm{M}$. Clinical study of recombinant human bone morphogenetic protein-2 in the treatment of nonunion of long bone in limbs. Journal of Huaihai Medicine. 2017;35(6):668-71.

23. Hackl S, Hierholzer C, Friederichs J, Woltmann A, Buhren V, von Ruden C. Long-term outcome following additional rhBMP-7 application in revision surgery of aseptic humeral, femoral, and tibial shaft nonunion. BMC Musculoskelet Disord. 2017:18(1):342.

24. Flierl MA, Smith WR, Mauffrey C, Irgit K, Williams AE, Ross E, Peacher G, Hak DJ, Stahel P. Outcomes and complication rates of different bone grafting modalities in long bone fracture nonunions: a retrospective cohort study in 182 patients. J Orthop Surg Res. 2013;8:33.

25. Schoelles K, Snyder D, Kaczmarek J, Kuserk E, Erinoff E, Turkelson C, Coates V (2005) The role of bone growth stimulating devices and orthobiologics in healing nonunion fractures. Rockville MD.

26. Garrison KR, Shemilt I, Donell S, Ryder JJ, Mugford M, Harvey I, Song FJ, Alt $\checkmark$. Bone morphogenetic protein (BMP) for fracture healing in adults. Cochrane Database Syst Rev. 2010;6:CD006950.

27. Kanakaris NK, Paliobeis C, Nlanidakis N, Giannousdis PV. Biological enhancement of tibial diaphyseal aseptic non-unions: the efficacy of autologous bone grafting, BMPs and reaming by-products. Injury. 2007; 38(Suppl 2):S65-75.

28. Sun YP, Qiao GY, Wang YB. Comparison between iliac autogaft combined bone morphogenetic protein and iliac autograft for bone nonunion. Chinese Journal of Tissue Engineering Research. 2009:13(33):6465-8.

29. Takemoto R, Forman J, Taormina DP, Egol KA. No advantage to rhBMP-2 in addition to autogenous graft for fracture nonunion. Orthopedics. 2014;37(6): e525-30.

30. Giorgio Calori M, Capanna R, Colombo M, Biase PD, O'Sullivan C, Cartareggia $\checkmark$, Conti C. Cost effectiveness of tibial nonunion treatment: a comparison between rhBMP-7 and autologous bone graft in two Italian centres. Injury. 2013;44(12):1871-9. 
31. Pape HC, Evans A, Kobbe P. Autologous bone graft: properties and techniques. J Orthop Trauma. 2010;24(Suppl 1):S36-40.

32. Dahabreh Z, Calori GM, Kanakaris NK, Nikolaou VS, Giannoudis PV. A cost analysis of treatment of tibial fracture nonunion by bone grafting or bone morphogenetic protein-7. Int Orthop. 2009;33(5):1407-14.

33. Hausmann M, Ehnert S, Hofmann V, Dobele S, Freude T, Stockle U, Nussler A. Use of bone morphogenetic proteins (BMPs) for the treatment of pseudarthroses - efficiency and therapy failure. Z Orthop Unfall. 2014;152(2):144-51.

34. Papanagiotou M, Dailiana ZH, Karachalios T, Varitimidis S, Vlychou M, Hantes M, Malizos KN. RhBMP-7 for the treatment of nonunion of fractures of long bones. Bone Joint J. 2015;97-B(7):997-1003.

\section{Publisher's Note}

Springer Nature remains neutral with regard to jurisdictional claims in published maps and institutional affiliations.

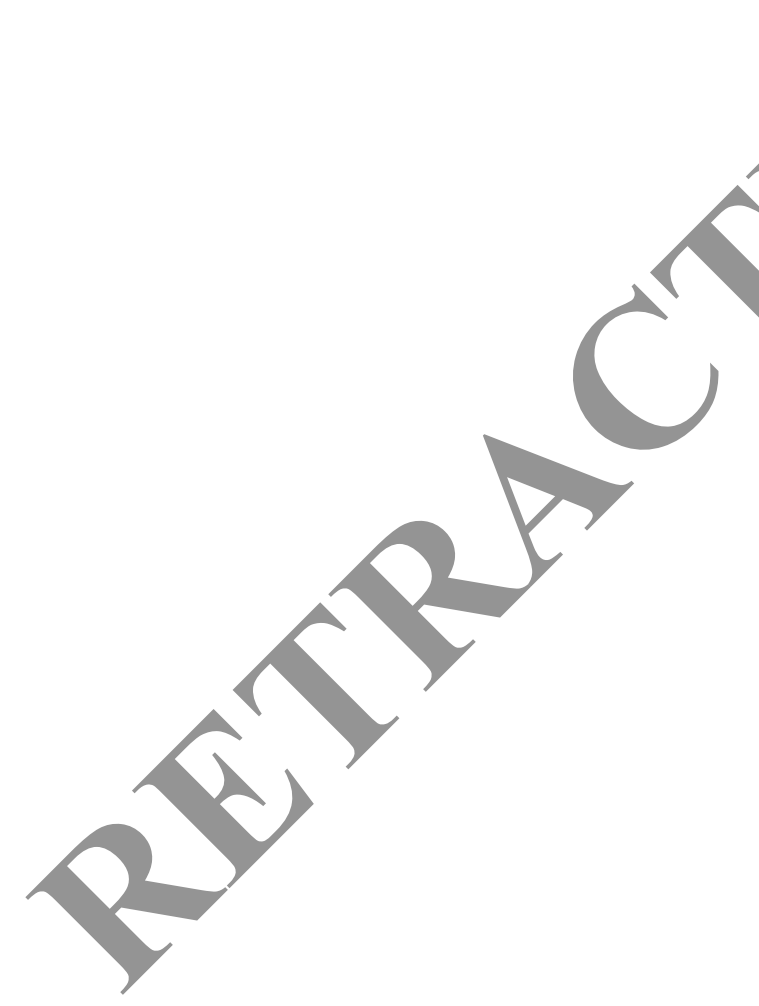

Ready to submit your research? Choose BMC and benefit from:

- fast, convenient online submission

- thorough peer review by experienced researchers in your field

- rapid publication on acceptance

- support for research data, including large and complex data types

- gold Open Access which fosters wider collaboration and increased citations

- maximum visibility for your research: over $100 \mathrm{M}$ website views per year

At $\mathrm{BMC}$, research is always in progress.

Learn more biomedcentral.com/submissions 